\title{
KESINAMBUNGAN FISKAL DAN ESTIMASI FISCAL REACTION FUNCTION INDONESIA TAHUN 1977-2017
}

\author{
Akhmad Solikin \\ Hilda Choirunnisah \\ Politeknik Keuangan Negara STAN \\ Alamat Korespondensi: akhsol@pknstan.ac.id
}

\begin{abstract}
This study aims to identify whether Indonesian fiscal condition in 1977-2017 is sustainable as measured by the government responses to debt burden. Studi on fiscal sustainability is very important since failing to identify its occurrence and determinants will detrimental to fiscal and macroeconomic policy. This study uses Auto-Regressive Distributed Lag-Error Correction Model (ARDL-ECM) to estimate short-term and long-term fiscal reaction functions. The result shows that in the long-term the government responds an increase in debt burden by increasing its primary balance and thus it confirms the existence of fiscal sustainability. Furthermore, by estimating fiscal reaction function this study finds that in the long run exchange rate and Asian Financial Crisis in 1998 have significant effects on primary balance; while in the short run real exchange rates, 1998 economic crisis, and commodity prices affect the primary balance.
\end{abstract}

\section{KATA KUNCI:}

Kesinambungan fiskal, Fiscal reaction function, Utang pemerintah, Keseimbangan primer

\section{ABSTRAK}

Penelitian ini bertujuan untuk mengetahui apakah keadaan fiskal Indonesia pada 1977-2017 berkesinambungan yang diindikasikan dengan adanya respon pemerintah terhadap peningkatan beban utang. Penelitian kesinambungan fiskal sangat penting karena kegagalan untuk mengidentifikasinya dan faktor-faktor yang memengaruhinya akan berpengaruh buruk terhadap kebijakan fiskal dan ekonomi makro. Model yang digunakan dalam penelitian ini adalah Auto-Regressive Distributed Lag-Error Correction Model (ARDL-ECM) yang mengestimasikan fiscal reaction function untuk persamaan jangka panjang dan jangka pendek. Hasil estimasi menunjukkan bahwa dalam jangka panjang, keseimbangan primer merespon peningkatan beban utang yang berarti kebijakan fiskal berkesinambungan. Selain itu, dengan mengestimasi fiscal reaction function, hasil penelitian menemukan bahwa dalam jangka panjang nilai tukar dan krisis Asia tahun 1998 berpengaruh signifikan; sedangkan dalam jangka pendek nilai tukar riil, krisis tahun 1998, dan harga komoditas turut memengaruhi keseimbangan primer secara signifikan.
\end{abstract}

KLASIFIKASI JEL:

C22, E62, H30, H63

CARA MENGUTIP: Solikin, A. \& Choirunnisah, H. (2019). Kesinambungan fiskal dan estimasi fiscal reaction function Indonesia Tahun 1977-2017. Indonesian Treasury Review: Jurnal Perbendaharaan, Keuangan Negara Dan Kebijakan Publik, $4(3), 267-283$. 


\section{PENDAHULUAN}

Pembiayaan utang merupakan salah satu instrumen yang digunakan pemerintah untuk menutupi defisit anggaran. Pada dasarnya pembiayaan utang merupakan instrumen yang dilematis, karena meskipun membantu pemerintah di masa kini sebagai sumber untuk menutupi kebutuhan anggaran, pembiayaan utang akan menimbulkan beban anggaran di masa yang akan datang (Rahmany, 2009).

Sebagaimana ditunjukkan pada Grafik 1, dalam beberapa tahun terakhir, pembiayaan utang pemerintah dari tahun ke tahun kian meningkat secara nominal meskipun nilai ini masih berada dalam batas yang diizinkan oleh undang-undang yaitu 60 persen dari PDB. Tingginya jumlah utang tidak hanya menjadi pengisi celah kekurangan anggaran pemerintah, namun juga berdampak pada postur anggaran pemerintah, salah satunya terlihat dari peningkatan belanja bunga.

Grafik 1. Rasio Utang terhadap PDB, Tahun 2005$2019(\%)$

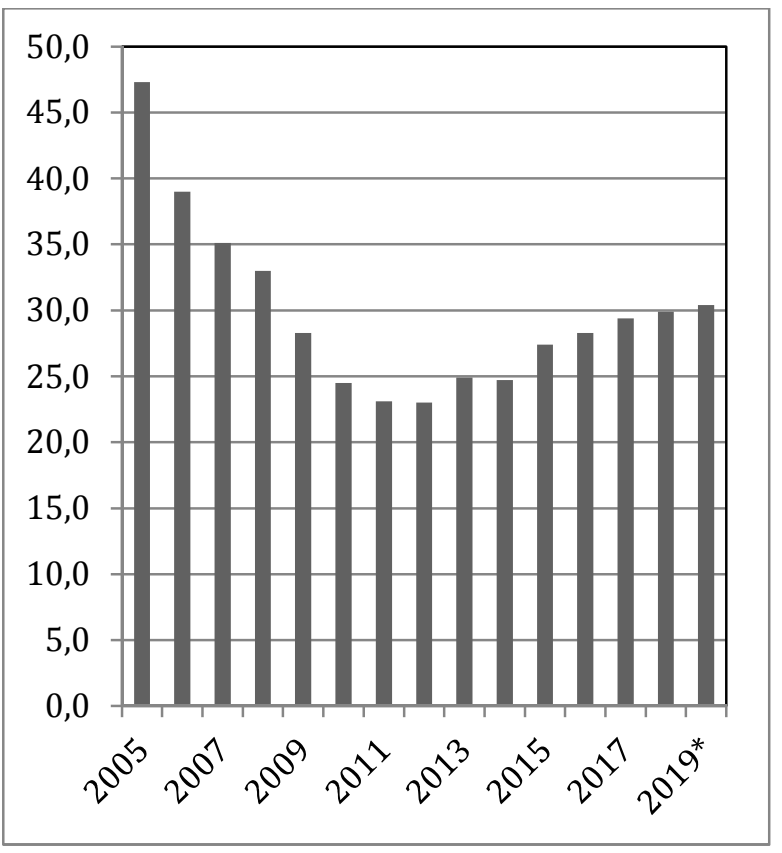

Catatan: * pada 2018 dan 2019= angka proyeksi

Sumber: DJA (2019)

Selain implikasi terhadap belanja, salah satu indikator yang perlu diperhatikan adalah keseimbangan primer. Sebagaimana tercantum pada Grafik 2, keseimbangan primer sejak tahun 2012 mengalami defisit setelah bertahun-tahun selalu berada di posisi yang positif. Keseimbangan primer merupakan indikator yang menggambarkan kemampuan pemerintah membayar pokok dan bunga utang dengan menggunakan pendapatan negara. Dengan demikian, jumlah yang defisit menunjukkan bahwa selama ini penerimaan negara belum dapat membayar bunga utang pemerintah atau dengan kata lain sebagian utang baru yang dilakukan pemerintah digunakan untuk membayar bunga utang sebelumnya (DJA, 2019).

Tekanan pembiayaan utang pada APBN pada akhirnya dapat menimbulkan masalah sustainabilitas atau kesinambungan fiskal (Rahmany, 2009). Kebijakan fiskal yang tidak berkesinambungan akan memberikan dampak buruk bagi pertumbuhan ekonomi, perekonomian sektor swasta, pengentasan kemiskinan, serta stabilitas ekonomi (Oyeleke \& Adebisi, 2014).

Grafik 2. Keseimbangan primer dan utang (dalam rasio terhadap PDB), Tahun 1977 - 2017

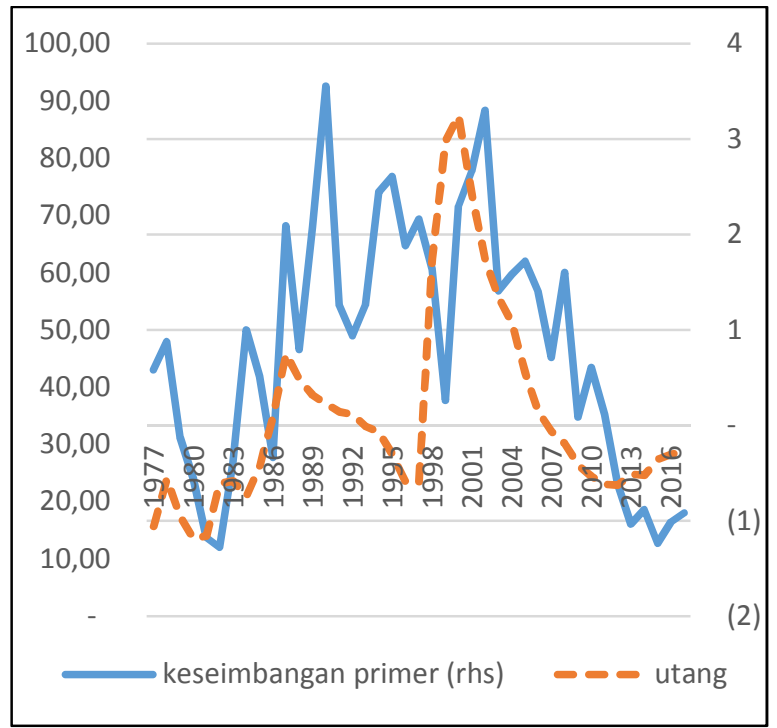

Sumber: diolah dari data NK APBN dan International Monetary Fund (n.d.-a)

Kesinambungan fiskal dapat menjadi suatu indikator kinerja pemerintah dalam mengelola kebijakan fiskal (Dinh, 1999). Kebijakan fiskal yang berkesinambungan menunjukkan bahwa kebijakan fiskal yang dilakukan telah tepat sehingga tidak perlu lagi dilakukan penyesuaian. Sebaliknya jika kebijakan fiskal yang diterapkan tidak berkesinambungan, pemerintah harus melakukan penyesuaian dalam pendapatan, belanja, atau utang agar kebijakan fiskal yang dilakukan dapat berkesinambungan (Marks, 2004).

Salah satu cara mengetahui kesinambungan fiskal suatu negara adalah melalui estimasi Fiscal Reaction Function yang dikembangkan oleh Bohn (2005). Pendekatan ini bertujuan untuk melihat perilaku anggaran pemerintah atas perubahan yang terjadi dalam pembiayaan utang sebagai indikator 
kesinambungan (Oyeleke \& Adebisi, 2014). Metode ini dianggap unggul untuk menilai kesinambungan utang karena menekankan pada hubungan antara keseimbangan primer dan utang pemerintah (Pamungkas, 2016), serta memenuhi konsep kesinambungan yang dinamis (Adams dkk, 2010). Namun demikian, untuk dapat melihat adanya korelasi antara keseimbangan primer dan rasio utang terhadap PDB diperlukan variabel-variabel kontrol yang merefleksikan peningkatan pengeluaran pemerintah yang temporer serta faktor-faktor terkait siklus perekonomian lainnya (Bohn, 2007).

Penelitian tentang kesinambungan fiskal untuk Indonesia telah dilakukan oleh beberapa peneliti, baik yang menggunakan data time series maupun data panel. Beberapa studi yang menggunakan data time series misalnya, Ascarya \& Yumanita (2004) meneliti kesinambungan fiskal Indonesia pada periode 1994-2002, Ramadhan \& Simanjuntak (2007) meneliti kasus Indonesia pada periode 1980-2005 yang dibagi menjadi tiga periode yaitu sebelum krisis, pada saat krisis, dan setelah krisis. Kuncoro (2011) meneliti periode 1999-2009, Lestari (2014) meneliti periode 19902012, Hakim \& Sriyana (2015) meneliti periode 1991-2010, Marisa (2015) meneliti periode 20002012, Mokoginta \& Stephanie (2015) meneliti periode 2000-2013, Wardhono dkk. (2015) meneliti periode 2004-2012, Pamungkas (2016) meneliti periode 1990-2014, Mudayen (2017) meneliti periode 1979-2016, dan Insukindro (2018) meneliti periode 2001-2016. Sementara, studi yang menggunakan data panel misalnya adalah Bui (2019) yang meneliti 22 negara berkembang di Asia termasuk Indonesia pada periode 1999-2017 serta Cruz-Rodriguez (2014) yang meneliti 18 negara sedang berkembang termasuk Indonesia pada periode 1990-2004.

Dari penelitian-penelitian tersebut mayoritas menyimpulkan adanya kesinambungan fiskal di Indonesia kecuali penelitian yang dilakukan oleh Ascarya \& Yumanita (2004), Kuncoro (2011), Cruz-Rodriguez (2014), Mokoginta \& Stephanie (2015), serta Mudayen (2017) yang menghasilkan simpulan yang berbeda. Ascarya \& Yumanita (2004) melaporkan secara umum terdapat kesinambungan kecuali tahun 1994 karena adanya masalah penerimaan negara dan periode 1998-1999 karena krisis ekonomi. Kuncoro (2011) menemukan bahwa kesinambungan fiskal sangat rapuh, Mokoginta \& Stephanie (2015) menemukan bahwa kebijakan fiskal di Indonesia tidak berkesinambungan dalam periode yang dianalisis (2000-2013), Hakim \& Sriyana (2015) menemukan ancaman kesinambungan dalam beberapa periode akibat guncangan eksternal, sedangkan Cruz-Rodriguez (2014) melaporkan bahwa pada periode 1990-2004 terdapat beberapa periode ketidaksinambungan, yaitu periode 1997:3-2000:1 akibat krisis ekonomi dan periode 2001:2-2004:4.

Seperti telah diulas sebelumnya bahwa keseimbangan primer Indonesia yang sejak tahun 2012 berada dalam posisi defisit menunjukkan bahwa pemerintah mengalami tekanan dalam membayar bunga utang. Kondisi tersebut perlu dianalisis lebih lanjut karena dapat meningkatkan risiko ketidaksinambungan. Hal tersebut ditunjukkan dari berbagai penelitian-penelitian sebelumnya yang memberikan simpulan berbeda terkait kesinambungan fiskal di Indonesia. Dengan adanya hasil penelitian yang berbeda, membuka peluang untuk melakukan penelitian pada topik yang sama dengan modifikasi variabel, menggunakan metode yang baru, dan/atau memperpanjang periode pengamatan.

Berdasarkan hal-hal tersebut, masalah penelitian yang diangkat adalah: (1) apakah kondisi fiskal Indonesia telah berkesinambungan pada periode 1977-2017? dan (2) variabel makroekonomi dan politik apakah yang memengaruhi keseimbangan fiskal? Selaras dengan masalah penelitian tersebut, penelitian ini bertujuan untuk (1) membuktikan ada tidaknya kesinambungan dalam kondisi fiskal di Indonesia dalam periode penelitian dan (2) mengidentifikasi faktor-faktor yang memengaruhi kesinambungan fiskal tersebut.

Inovasi dalam penelitian ini adalah (1) menggunakan periode pengamatan yang lebih panjang dan (2) menggunakan harga komoditas ekspor utama Indonesia yaitu sawit dan batu bara, serta variabel harga minyak sebagai variabel independen. Hasil penelitian ini berguna bagi para pengambil kebijakan di instansi pemerintah, khususnya Kementerian Keuangan dalam menentukan kebijakan fiskal terkait defisit anggaran dan pengelolaan utang. Selain itu, hasil penelitian juga bermanfaat bagi dunia akademik dengan memperkaya variabel ekonomi makro dan sosial dalam analisis kesinambungan fiskal.

\section{LANDASAN TEORI}

\subsection{Peran Belanja Pemerintah}

Peran pemerintah dalam perekonomian dapat dilakukan dengan peran pengaturan (reguleren) dengan membuat peraturan untuk 
menjamin keselarasan kepentingan perusahaan, pekerja, konsumen, dan masyarakat secara umum. Selain itu, peran yang sangat penting yaitu negara melalui pemerintah berhak mengenakan pajak sebagai sumber utama pendapatan negara. Pendapatan tersebut kemudian dibelanjakan untuk penyediaan barang dan jasa publik untuk mencapai kesejahteraan masyarakat. Dengan demikian, hubungan antara pendapatan dan belanja sangat erat.

Dalam studi keuangan publik, terdapat pendapat yang menyatakan bahwa pendapatan pajak akan memengaruhi belanja, pengeluaran belanja akan meningkatkan penerimaan pajak, atau hubungan timbal balik dua arah antara pendapatan dan belanja (Sriyana, 2012). Hasil review atas penelitian empiris menunjukkan bahwa ketiga jenis hubungan tersebut dilaporkan dalam penelitian di negara sedang berkembang (Solikin, 2018). Dikaitkan dengan belanja, pada umumnya pemerintah menganut pandangan Keynesian daripada pandangan Wagner, yaitu peran pemerintah sangat penting dalam perekonomian dengan menggunakan belanja (APBN) untuk menggerakkan perekonomian, setidaknya dalam jangka pendek.

Peran menggerakkan perekonomian tersebut menjadi sangat penting terutama apabila sektor swasta kurang mampu berperan. Hal tersebut dapat ditunjukkan misalnya dalam kondisi krisis ekonomi, swasta mengurangi investasi sehingga pemerintah harus berperan dengan melakukan kebijakan belanja ekspansif. Kebijakan tersebut dikenal sebagai counter cyclical fiscal policy (Combes dkk, 2017). Berdasarkan pandangan tersebut, pemerintah dianjurkan menambah belanja pada saat krisis dan meningkatkan penerimaan pajak atau tabungan ketika ekonomi dalam kondisi baik. Justru, hal tersebut akan menimbulkan masalah ketika kebutuhan untuk belanja yang ekspansif dalam kondisi krisis ekonomi ternyata tidak didukung oleh pendapatan atau tabungan pemerintah yang kuat. Hal tersebut terjadi karena dalam kondisi krisis, ruang gerak pemerintah tidak leluasa meningkatkan pajak sehingga pemerintah menambah utang asalkan bisa mendiversifikasikan sumber pendapatan non-pajak (Zhang, 2015). Penambahan utang tersebut tanpa menambah pendapatan dapat memperparah defisit dan mengurangi kesinambungan fiskal.

\subsection{Intertemporal Budget Constraint}

Pada umumnya kesinambungan fiskal diukur dengan intertemporal budget costraint. Kekangan anggaran pada berbagai waktu menunjukkan bahwa boleh saja meningkatkan utang (defisit) pada suatu waktu, tetapi harus ditutup dengan surplus pada periode yang lain, sehingga dalam jangka panjang tetap terjaga kesinambungannya, dalam artian tidak melakukan Ponzi Game yaitu mendapatkan utang baru untuk menutup utang yang lama.

Wickens (2008) menyebutkan bahwa kondisi kesinambungan defisit fiskal dapat terpenuhi hanya jika kondisi intertemporal budget constraint dapat dipenuhi. Dengan kondisi yang berkesinambungan, pemerintah dapat melakukan pembiayaan utang dan sektor swasta memiliki keyakinan terhadap pinjaman dan obligasi yang diterbitkan pemerintah. Untuk itu, dalam melakukan pembiayaan utang, pemerintah harus memiliki keyakinan bahwa utang yang dilakukan saat ini mampu dibayar dengan pendapatan negara di masa mendatang. Dengan demikian pembayaran utang bersifat terbatas atau tidak dilakukan selamanya (Jadhav \& Neelankavil, 2011).

Tanner \& Samake (2008) mendefinisikan kesinambungan fiskal sebagai kondisi ketika present value budget constraint terpenuhi tanpa adanya perubahan yang signifikan terhadap keseimbangan primer akibat adanya biaya utang yang terjadi. Sementara itu, Adams dkk, (2010) menyatakan bahwa sebuah kebijakan fiskal adalah berkesinambungan jika anggaran pemerintah dapat dibiayai dengan baik tanpa adanya peningkatan jumlah utang publik atau peredaran uang yang terlalu tinggi.

Present value budget constraint merupakan konsep kesinambungan fiskal yang dikembangkan dari teori intertemporal budget constraint. Menurut teori ini, pemerintah memberi stimulus secara temporer pada perekonomian. Stimulus yang bersifat temporer tersebut dapat dilakukan dengan mengurangi pajak atau melakukan pembiayaan utang. Pemotongan pajak dan utang yang dilakukan masa kini diharapkan dapat dibayar kembali oleh pendapatan pemerintah di masa mendatang (Wickens, 2008). Untuk memenuhi kebijakan fiskal yang berkesinambungan, kondisi intertemporal budget constraint haruslah terpenuhi yaitu bahwa intervensi pemerintah berupa pembiayaan tersebut hanya dilakukan secara temporer (Wickens, 2008). Untuk itu, present value surplus primer pemerintah haruslah dapat membayar utang pemerintah saat ini (Quintos, 1995; Tronzano, 2013), untuk itu present value dari utang pemerintah akan berkonvergensi menjadi nol di masa mendatang (Cuddington, 1997; Hakkio dan Rush, 1991; Trehan dan Walsh, 1991). Kebijakan fiskal yang berkesinambungan mengharuskan syarat No-Ponzi Game atau tidak adanya utang yang terakumulasi 
secara terus menerus lebih cepat dibanding kemampuan membayar utang (Trehan \& Walsh, 1991).

Present value budget constraint menyatakan bahwa nilai diskonto dari surplus pemerintah diharapkan mampu membayar utang pemerintah seiring berjalannya waktu (Mendoza \& Oviedo, 2003; Tronzano, 2013). Dalam jangka pendek, pemerintah dapat mengalami baik surplus maupun defisit secara bergantian (Jadhav \& Neelankavil, 2011). Namun dalam jangka panjang akan terdapat keseimbangan antara keseimbangan primer dan pembiayaan utang yang dilakukan pemerintah (Dinh, 1999).

\section{METODE PENELITIAN}

Variabel yang digunakan dalam penelitian ini dapat dikategorikan sebagai variabel dependen, variabel independen, dan variabel kontrol. Variabel dependen dalam penelitian ini adalah rasio keseimbangan primer terhadap PDB (RPBAL) yang digunakan sebagai proksi dari reaksi pemerintah. Variabel independen yang digunakan adalah rasio utang terhadap PDB (RDEBT).

Variabel kontrol yang digunakan dalam persamaan dasar Bohn (2005) adalah output gap. Menurut Lestari (2014), output gap dapat menjadi variabel kontrol dalam persamaan reaksi fiskal sebagai penjelas jika pemerintah menggunakan kebijakan fiskal untuk mendorong adanya stabilisasi jangka pendek atau dengan kata lain bereaksi terhadap siklus ekonomi.

Untuk mencirikan karakter spesifik negara, Bohn (2005) mengembangkan persamaan reaksi fiskal dengan menggunakan variabel kontrol yang mencerminkan determinan keseimbangan primer dalam jangka pendek. Penelitian yang berbeda menawarkan variabel kontrol yang berbeda pula. Penelitian yang dilakukan oleh Marisa (2015), Mokoginta \& Stephanie (2015), dan Pamungkas (2016) menggunakan variabel suku bunga dan inflasi sebagai pengaruh dari kebijakan moneter terhadap kebijakan fiskal. Variabel inflasi yang merupakan representasi dari sektor moneter berdampak signifikan pada penelitian yang dilakukan oleh Mokoginta \& Stephanie (2015) dan Wardhono dkk, (2015). Variabel nilai tukar digunakan dalam penelitian Marisa (2015), Mokoginta \& Stephanie (2015), Pamungkas (2016), dan Insukindro (2018) dan menunjukkan adanya pengaruh nilai tukar terhadap keseimbangan primer. Peningkatan nilai tukar akan menyebabkan adanya peningkatan utang eksternal karena pinjaman luar negeri pada umumnya dinyatakan dalam mata uang dolar. Selain itu, salah satu variabel yang berpengaruh dalam kebijakan fiskal Indonesia adalah harga komoditas terutama minyak (Wardhono dkk, 2015) yang terlihat dari tingginya penerimaan negara dari barang komoditas.

Merujuk pada penelitian-penelitian terdahulu, dalam penelitian ini terdapat variabel kontrol yang mencerminkan determinan lain yang berpengaruh pada kebijakan fiskal atau shock yang memengaruhi kebijakan fiskal. Variabel kontrol yang digunakan dalam penelitian ini antara lain adalah output gap (GDP_GAP), inflasi (INF), nilai tukar nominal (ER) atau nilai tukar riil (RER), suku bunga nominal (IR) atau suku bunga riil (RIR), rata-rata harga komoditas (COM) atau harga minyak (BRENT), dummy krisis 1998 (DUM98) dan dummy pemilihan presiden (DUM_PEMILU).

Metode penelitian yang digunakan adalah estimasi persamaan reaksi fiskal atau Fiscal Reaction Function yang dikembangkan oleh Bohn (2005, 2007). Fungsi reaksi merujuk pada mekanisme koreksi kesalahan (error correction) yang memiliki interpretasi ekonomi sebagai perilaku entitas yang diteliti (Bohn, 2007). Jika pemerintah bereaksi terhadap peningkatan beban utang dengan meningkatkan surplus primer, risiko keuangan pemerintah akan menjadi rendah (Aso, 2013). Untuk itu, kebijakan fiskal diindikasikan berkesinambungan jika koefisien rasio utang terhadap PDB adalah positif yang mengimplikasikan bahwa ada reaksi pemerintah terhadap peningkatan beban utang (Adams et al., 2010). Penggunaan metode fiscal reaction function untuk Indonesia telah dilakukan oleh beberapa peneliti, misalnya Lestari (2014), Marisa (2015), Mokoginta \& Stephanie (2015), Pamungkas (2016), Insukindro (2018), dan Bui (2019).

Model ekonometrika yang digunakan disajikan dalam rumus (1a), (1b), (1c), dan (1d). Variasi dalam model terjadi karena pembedaan penggunaan variabel nilai tukar nominal (ER) atau nilai tukar riil (RER), suka bunga nominal (IR) atau suka bunga riil (RIR) serta harga komoditas (COM) atau harga minyak BRENT.

$R P B A L_{t}=\alpha_{0}+\alpha_{1} R D E B T_{t}+\beta_{1} G D P_{-} G A P_{t}+$ $\beta_{2} I N F_{t}+\beta_{3} E R_{t}+\beta_{4} I R_{t}+\beta_{5} C O M_{t}+$ $\beta_{6} D U M_{-} P E M I L U_{t}+\beta_{7} D U M 98_{t}+\varepsilon_{t} \ldots \ldots \ldots \ldots . . .(1 \mathrm{a})$

$R P B A L_{t}=\alpha_{0}+\alpha_{1} R D E B T_{t}+\beta_{1} G D P_{-} G A P_{t}+$ $\beta_{2} I N F_{t}+\beta_{3} E R_{t}+\beta_{4} I R_{t}+\beta_{5} B R E N T_{t}+$ $\beta_{6} D U M_{-} P E M I L U_{t}+\beta_{7} D U M 98_{t}+\varepsilon_{t}$. 
$R P B A L_{t}=\alpha_{0}+\alpha_{1} R D E B T_{t}+\beta_{1} G D P_{-} G A P_{t}+$ $\beta_{2} I N F_{t}+\beta_{3} R E R_{t}+\beta_{4} R I R_{t}+\beta_{5} C O M_{t}+$ $\beta_{6} D U M_{-} P E M I L U_{t}+\beta_{7} D U M 98_{t}+\varepsilon_{t}$

$R P B A L_{t}=\alpha_{0}+\alpha_{1} R D E B T_{t}+\beta_{1} G D P_{-} G A P_{t}+$ $\beta_{2} I N F_{t}+\beta_{3} R E R_{t}+\beta_{4} R I R_{t}+\beta_{5} B R E N T_{t}+$ $\beta_{6} D U M_{-} P E M I L U_{t}+\beta_{7} D U M 98_{t}+\varepsilon_{t} \ldots \ldots \ldots \ldots . . .(1 \mathrm{~d})$

Keterangan:

$R P B A L_{t}=$ rasio keseimbangan primer terhadap PDB pada periode $t$,

$R D E B T_{t}=$ rasio utang terhadap PDB pada periode t, $G D P_{-} G A P_{t}=$ output gap pada periode $\mathrm{t}$,

$I N F_{t}=$ inflasi pada periode $\mathrm{t}$,

$E R_{t}=$ nilai tukar nominal pada periode $\mathrm{t}$,

$R E R_{t}=$ nilai tukar riil pada periode $\mathrm{t}$,

$I R_{t}=$ suku bunga nominal pada periode $\mathrm{t}$,

$R I R_{t}=$ suku bunga riil pada periode $\mathrm{t}$,

$\mathrm{COM}_{t}=$ harga komoditas pada periode $\mathrm{t}$,

$B R E N T_{t}=$ harga minyak pada periode $\mathrm{t}$,

$D U M \_P E M I L U=$ dummy kegiatan pemilihan umum,

DUM98= dummy krisis moneter tahun 1998 ,

$\alpha_{0}=$ intersep,

$\alpha_{1}=$ koefisien kesinambungan,

$\beta_{i}=$ koefisien yang menunjukkan dampak dari variabel determinan, dan

$\varepsilon_{\mathrm{t}}=$ error

Pendekatan analisis data yang digunakan dalam penelitian ini adalah model Autoregressive Distributed-Lag (ARDL). ARDL adalah model dinamis yang menangkap adanya pengaruh waktu atau nilai di masa sebelumnya (lag) terhadap variabel dependen (Pesaran, Shin, dan Smith, 2001). Penggunaan model ini dilandasi oleh asumsi bahwa terdapat lag atau rentang waktu untuk variabel independen bereaksi atas perubahan variabel dependen. Lag umum dilakukan pada model-model yang menggambarkan fenomena riil dan biasanya terjadi karena alasan psikologis, teknologi, dan institusi (Gujarati, 2003). Model ARDL adalah model yang relatif sederhana karena dapat diestimasi dengan metode Ordinary Least Squares (OLS). Tahapan uji-uji yang dilakukan meliputi uji stasioneritas, uji lag optimum, dan uji kointegrasi.

Data yang digunakan dalam penelitian ini adalah data sekunder runtut waktu (time series) pada periode 1977-2017. Sebagaimana dilaporkan oleh Paparas, Richter dan Paparas (2015) mayoritas penelitian tentang kesinambungan fiskal menggunakan data runtun waktu, meskipun untuk negara sedang berkembang data yang tersedia umumnya tidak terlalu panjang. Untuk menambah jumlah observasi dapat digunakan data kuartalan. Dalam penelitian ini, data tahunan digunakan untuk mencerminkan reaksi pemerintah mengingat bahwa kebijakan fiskal di Indonesia terutama dalam bentuk APBN bersifat tahunan.

Data yang digunakan dalam penelitian meliputi data realisasi anggaran pemerintah (baik realisasi penerimaan maupun pengeluaran pemerintah), belanja bunga, data utang pemerintah, data PDB, data inflasi, suku bunga riil, harga komoditas, dan data nilai tukar rupiah. Data diperoleh dari laporan maupun basis data berbagai institusi. Tabel 1 menunjukkan sumber data secara umum.

Tabel 1. Sumber Data

\begin{tabular}{|l|l|}
\hline \multicolumn{1}{|c|}{ Data } & \multicolumn{1}{c|}{ Sumber } \\
\hline $\begin{array}{l}\text { Realisasi penerimaan } \\
\text { pemerintah, } \\
\text { Realisasi pengeluaran } \\
\text { pemerintah }\end{array}$ & $\begin{array}{l}\text { Kementerian Keuangan, } \\
\text { Statistik Ekonomi Keuangan } \\
\text { Indonesia Bank Indonesia }\end{array}$ \\
\hline $\begin{array}{l}\text { Utang Pemerintah } \\
\text { Pusat }\end{array}$ & Kementerian Keuangan \\
\hline $\begin{array}{l}\text { Rasio utang terhadap } \\
\text { PDB }\end{array}$ & IMF Data Mapper \\
\hline $\begin{array}{l}\text { Produk Domestik } \\
\text { Bruto (PDB) }\end{array}$ & Badan Pusat Statistik \\
\hline Inflasi & $\begin{array}{l}\text { Federal Reserve Bank of St. } \\
\text { Louis }\end{array}$ \\
\hline Nilai Tukar Nominal & $\begin{array}{l}\text { International Financial } \\
\text { Statistic, IMF }\end{array}$ \\
\hline Nilai Tukar Riil & $\begin{array}{l}\text { International Financial } \\
\text { Statistic, IMF }\end{array}$ \\
\hline Suku Bunga Nominal & $\begin{array}{l}\text { International Financial } \\
\text { Statistic, IMF }\end{array}$ \\
\hline Suku Bunga Riil & World Bank \\
\hline Harga Komoditas & World Bank \\
\hline
\end{tabular}

Sumber: diolah penulis

\section{HASIL PENELITIAN}

Bagian ini menjelaskan mengenai hasil uji-uji data runtun waktu yang meliputi uji stasionaritas, uji lag optimum, dan uji kointegrasi. Kemudian bagian ini juga akan melaporkan hasil metode ARDL-ECM beserta pembahasan hasil tersebut.

\subsection{Uji Stasioneritas}

Uji stationeritas perlu dilakukan terutama pada data runtut waktu. Data yang tidak stationer akan menyebabkan regresi lancung atau tidak bermakna. Uji yang dilakukan dalam penelitian ini adalah uji akar unit (unit root test) dengan metode Augmented Dickey Fuller (ADF) dan Philip Peron (PP). Hasil dari uji akar unit terhadap variabel yang digunakan dalam penelitian ini ditunjukkan dalam Tabel 2. Pada level, terdapat variabel yang tidak 
stasioner, sedangkan pada pembedaan pertama (first difference) semua variabel sudah stasioner.

Tabel 2. Hasil Uji Stasioneritas

\begin{tabular}{|l|c|c|c|c|}
\hline \multirow{2}{*}{ Var } & \multicolumn{2}{|c|}{ ADF } & \multicolumn{2}{c|}{ PP } \\
\cline { 2 - 5 } & Level & $\begin{array}{c}\text { 1st } \\
\text { diff }\end{array}$ & Level & 1st diff \\
\hline RPBAL & $-2,356$ & $-8,154^{* *}$ & $-2,180$ & $-9,104^{* *}$ \\
\hline RDEBT & $-2,684^{* *}$ & $-4,344^{* *}$ & $-2,125$ & $-3,475^{* *}$ \\
\hline GDP_GAP & $-3,458^{* *}$ & $-5,450^{* *}$ & $-2,882^{*}$ & $-6,185^{* *}$ \\
\hline INF & $-5,097^{* *}$ & $-7,805^{* *}$ & $-5,097^{* *}$ & $-25,636^{* *}$ \\
\hline ER & $-0,453$ & $-7,436^{* * *}$ & $-0,206$ & $-7,458^{* * *}$ \\
\hline RER & $-3,324^{*}$ & $-5,587^{* *}$ & $-3,436^{*}$ & $-5,599^{* *}$ \\
\hline IR & $-2,779^{*}$ & $-5,490^{* *}$ & $-2,772^{*}$ & $-8,977^{* * *}$ \\
\hline RIR & $-5,536^{* *}$ & $-7,503^{* *}$ & $-5,549^{* *}$ & $-19,312^{* *}$ \\
\hline BRENT & $-1,525$ & $-5,606^{* *}$ & $-1,585$ & $-5,606^{* *}$ \\
\hline COM & $-1,522$ & $-5,975^{* *}$ & $-1,535$ & $-5,975^{* *}$ \\
\hline
\end{tabular}

Keterangan: ${ }^{* * *}=$ stasioner pada tingkat sig. $1 \%,{ }^{* *}=$ stasioner pada tingkat sig. $5 \%,^{*}=$ stasioner pada tingkat sig. $10 \%$

Sumber: diolah penulis

\subsection{Lag Optimum}

Uji lag optimum dilakukan untuk menentukan model terbaik. Penentuan lag dilakukan berdasarkan kriteria antara lain Akaike Information Criterion (AIC) dan Schwarz Bayesian Criterion (SBC). Hasil dari uji lag optimum menunjukkan bahwa kondisi optimal terjadi pada lag 1 hingga lag 3. Hasil pengujian lag optimum secara lengkap dapat dilihat di lampiran.

\subsection{Uji Kointegrasi dan ARDL-ECM}

Uji kointegrasi perlu dilakukan mengingat tidak semua variabel stasioner pada tingkat level sehingga dapat menyebabkan adanya regresi lancung atau spurious regression. Hasi uji kointegrasi dengan menggunakan metode ARDL bound menyatakan bahwa terdapat hubungan jangka panjang antar variabel. Dengan adanya kointegrasi dalam persamaan, maka terdapat mekanisme kesalahan (error correction) dalam persamaan yang dapat diestimasi. Dengan adanya kointegrasi, pendekatan yang digunakan adalah ARDL-ECM. Hasil pengujian kointegrasi secara lengkap dapat dilihat di lampiran.
Model ARDL memiliki output model jangka panjang dan model jangka pendek. Persamaan jangka panjang yang diestimasi memiliki tiga variabel yang signifikan pada tingkat keyakinan 5 persen yaitu rasio utang terhadap PDB, nilai tukar riil dan dummy krisis tahun 1998. Persamaan error correction mechanism (ECM) yang diestimasi memberikan nilai ECT yang negatif dan signifikan sehingga persamaan ECM yang ditunjukkan adalah valid. Variabel yang berpengaruh dalam persamaan ECM antara lain adalah variabel rasio utang, nilai tukar rill, harga komoditas dan dummy tahun 1998. Uji kesesuaian model dicantumkan pada Tabel 3. Hasil model jangka panjang disajikan pada Tabel 4 dan hasil model jangka pendek pada Tabel 5 .

Dari hasil uji kesesuaian model sebagaimana tercantum pada Tabel 3 diketahui bahwa semua model (Model 1a, Model 1b, Model 1c, dan Model 1d) signifikan karena memiliki nilai probabilitas $F$ statistic yang lebih rendah daripada 5 persen, bahkan memenuhi kriteria signifikansi 1 persen. Variabel-variabel dalam model dapat menjelaskan variasi dalam kesinambungan fiskal sekitar 70-76 persen. Dengan demikian, terdapat variabelvariabel lain yang tidak dimasukkan dalam model yang bisa menjelaskan antara 30-24 persen dari faktor-faktor yang memengaruhi keseimbangan fiskal.

Tabel 3. Uji Kesesuaian Model

\begin{tabular}{|c|c|c|c|c|}
\hline Kriteria & $\begin{array}{c}\text { Model } \\
1 \mathrm{a}\end{array}$ & $\begin{array}{c}\text { Model } \\
\text { 1b }\end{array}$ & $\begin{array}{l}\text { Model } \\
\text { 1c }\end{array}$ & $\begin{array}{l}\text { Model } \\
\text { 1d }\end{array}$ \\
\hline R-squared & 0,788 & 0,790 & 0,833 & 0,834 \\
\hline Adj. R-Sq. & 0,691 & 0,693 & 0,756 & 0,757 \\
\hline F-statistic & 8,096 & 8,157 & 10,839 & 10,916 \\
\hline Prob F-stat. & 0,000 & 0,000 & 0,000 & 0,000 \\
\hline Akaike AIC & 2,525 & 2,519 & 2,288 & 2,282 \\
\hline Schwarz SC & 3,079 & 3,073 & 2,842 & 2,837 \\
\hline $\begin{array}{l}\text { Hannah- } \\
\text { Quinn }\end{array}$ & 2,724 & 2,718 & 2,387 & 2,481 \\
\hline $\begin{array}{l}\text { Durbin- } \\
\text { Watson stat }\end{array}$ & 1,716 & 1,667 & 1,706 & 1,676 \\
\hline
\end{tabular}

Sumber: Hitungan penulis 
Tabel 4. Hasil Model Jangka Panjang

\begin{tabular}{|c|c|c|c|c|}
\hline \multirow{2}{*}{ Variabel } & \multicolumn{4}{|c|}{ Koefisien } \\
\hline & Model 1a & Model 1b & Model 1c & Model 1d \\
\hline \multirow{2}{*}{ RDEBT } & 0,120917 & 0,117674 & 0,074633 & 0,071318 \\
\hline & $(4,454)^{* * *}$ & $(4,403)^{* * *}$ & $(3,356)^{* * *}$ & $(3,340)^{* * *}$ \\
\hline \multirow{2}{*}{ GDP_GAP } & 0,000002 & 0,000002 & 0,000001 & 0,000001 \\
\hline & $(1,361)$ & $(1,264)$ & $(0,952)$ & $(0,364)$ \\
\hline \multirow{2}{*}{ INF } & 0,037200 & 0,032086 & 0,000311 & $-0,000534$ \\
\hline & $(1,007)$ & $(0,867)$ & $(0,009)$ & $(0,986)$ \\
\hline ER & $\begin{array}{r}0,000203 \\
(0,952)\end{array}$ & $\begin{array}{r}0,000238 \\
(1,0661)\end{array}$ & & \\
\hline \multirow{2}{*}{ RER } & & & $-0,010337$ & $-0,010522$ \\
\hline & - & - & $(-2,929)^{* * *}$ & $(-3,037)^{* * *}$ \\
\hline IR & $\begin{array}{r}-0,049293 \\
(-0,688) \\
\end{array}$ & $\begin{array}{r}-0,044536 \\
(-0,617) \\
\end{array}$ & 2 & 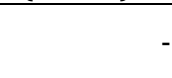 \\
\hline RIR & 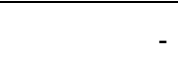 & 20 & $\begin{array}{r}-0,028615 \\
(-1,085)\end{array}$ & $\begin{array}{r}-0,026924 \\
(-1,031)\end{array}$ \\
\hline $\mathrm{COM}$ & $\begin{array}{r}0,022245 \\
(1,373)\end{array}$ & - & $\begin{array}{r}0,008423 \\
(0,745)\end{array}$ & $(-10-2)$ \\
\hline BRENT & 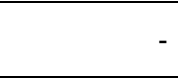 & $\begin{array}{r}0,019375 \\
(1,248)\end{array}$ & & $\begin{array}{r}0,006328 \\
(0,599)\end{array}$ \\
\hline \multirow{2}{*}{ DUM_PEMILU } & 0,158234 & 0,151133 & 0,081944 & 0,072664 \\
\hline & $(0,337)$ & $(0,322)$ & $(0,249)$ & $(0,225)$ \\
\hline \multirow{2}{*}{ DUM98 } & $-4,645126$ & $-4,818359$ & $-2,413150$ & $-2,312998$ \\
\hline & $(-1,970)^{*}$ & $(-1,977)^{*}$ & $(-3,650)^{* * *}$ & $(-3,585)^{* * *}$ \\
\hline \multirow{2}{*}{$\mathrm{C}$} & $-2,757897$ & $-2,659148$ & 0,551418 & 0,740080 \\
\hline & $(-1,413)^{* * *}$ & $(0,181)$ & $(0,418)$ & $(0,593)$ \\
\hline ARDL & $1,2,0,0,0,0,1$ & $1,2,0,0,0,0,1$ & $1,2,0,0,0,0,1$ & $1,2,0,0,0,0,1$ \\
\hline Observasi & 39 & 39 & 39 & 39 \\
\hline
\end{tabular}

Keterangan: ${ }^{* * *}=\operatorname{sig} .1 \%,{ }^{* *}=\operatorname{sig} .5 \%,{ }^{*}=$ sig. $10 \%$; $t$-statistic dalam kurung

Sumber: Hitungan penulis

\subsection{Pembahasan}

Rasio utang terhadap PDB menunjukkan pengaruh yang signifikan pada tingkat keyakinan lima persen. Arah yang ditunjukkan oleh rasio utang terhadap PDB adalah positif. Hal ini menunjukkan bahwa dalam jangka panjang, adanya peningkatan rasio utang terhadap PDB akan direspon pemerintah dengan meningkatkan rasio keseimbangan primer terhadap PDB. Pada Grafik 2 dapat dilihat bahwa antara keseimbangan primer dan utang menunjukkan tren yang sejalan.

Berdasarkan kerangka present value budget constraint adanya peningkatan surplus primer dimaksud ditujukan untuk membayar beban utang yang meningkat sehingga tidak terjadi Ponzi Game atau utang yang terakumulasi terus menerus tanpa adanya kemampuan membayar. Hasil ini selaras dengan simpulan yang diperoleh beberapa penelitian terdahulu misalnya oleh Ramadhan dan Simanjuntak (2007), Lestari (2014), Hakim dan Sriyana (2015), Marisa (2015), Wardhono et al. (2015), Pamungkas (2016), Insukindro (2018), Nurhayati dan Wahyuningsih (2018), dan Bui (2019); yang menyatakan bahwa kondisi kebijakan fiskal di Indonesia berkesinambungan.
Menurut hasil estimasi jangka panjang, reaksi pemerintah dalam hal ini rasio utang pemerintah terhadap PDB akan meningkat 0,09 persen dengan peningkatan 1 persen utang. Jika diubah dalam angka nominal dengan menggunakan PDB tahun 2017, interpretasi tersebut dapat berarti dalam jangka panjang peningkatan utang sekitar 135 milyar rupiah akan membuat pemerintah merespon dengan meningkatkan surplus primer sebesar 12 milyar rupiah untuk mempertahankan kesinambungannya.

Sementara itu, respon jangka pendek pemerintah atas perubahan terhadap rasio utang terhadap PDB signifikan pada Model $1 \mathrm{a}$ dan $1 \mathrm{~b}$, tetapi tidak signifikan pada Model 1c dan 1d. Pada periode berjalan, pemerintah akan sulit merespon secara langsung peningkatan beban utang pada periode yang sama meskipun dapat saja dilakukan dengan meningkatkan pendapatan atau melakukan penghematan anggaran. Di lain pihak, rasio utang terhadap PDB pada periode tahun sebelumnya signifikan pada tingkat 1 persen, menunjukkan fleksibilitas respon pemerintah terhadap kinerja fiskal tahun sebelumnya. 
Tabel 5. Hasil Model Jangka Pendek

\begin{tabular}{|c|c|c|c|c|}
\hline \multirow{2}{*}{ Variabel } & \multicolumn{4}{|c|}{ Koefisien } \\
\hline & Model 1a & Model 1b & Model 1c & Model 1d \\
\hline RDEBT & $\begin{array}{l}0,062958 \\
(2,199)^{* *}\end{array}$ & $\begin{array}{l}0,063160 \\
(2,208)^{* *}\end{array}$ & $\begin{array}{r}0,039219 \\
(1,352)\end{array}$ & $\begin{array}{r}0,038273 \\
(1,326)\end{array}$ \\
\hline RDEBT(-1) & $\begin{array}{r}-0,059284 \\
(-2,956)^{* * *}\end{array}$ & $\begin{array}{r}-0,059751 \\
(-2,991)^{* * *}\end{array}$ & $\begin{array}{r}-0,060449 \\
(-3,379)^{* * *}\end{array}$ & $\begin{array}{r}-0,060766 \\
(-3,414)^{* * *}\end{array}$ \\
\hline GDP_GAP & $\begin{array}{r}0,000002 \\
(1,287) \\
\end{array}$ & $\begin{array}{r}0,000001 \\
(1,199) \\
\end{array}$ & $\begin{array}{r}0,000001 \\
(0,957) \\
\end{array}$ & $\begin{array}{r}0,000001 \\
(0,926) \\
\end{array}$ \\
\hline INF & $\begin{array}{r}0,027269 \\
(0,974) \\
\end{array}$ & $\begin{array}{r}0,023373 \\
(0,841) \\
\end{array}$ & $\begin{array}{r}0,000278 \\
(-0,009)\end{array}$ & $\begin{array}{r}-0,000482 \\
(-0,016)\end{array}$ \\
\hline ER & $\begin{array}{r}0,000149 \\
(1,011) \\
\end{array}$ & $\begin{array}{r}0,000173 \\
(1,144) \\
\end{array}$ & 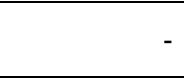 & \\
\hline RER & ( & ( & $\begin{array}{l}-0,009239 \\
(-2,565)^{* *}\end{array}$ & $\begin{array}{l}-0,009490 \\
(-2,648)^{* *}\end{array}$ \\
\hline IR & $\begin{array}{r}-0,036133 \\
(-0,688) \\
\end{array}$ & $\begin{array}{r}-0,032442 \\
(-0,616) \\
\end{array}$ & $e^{2}$ & 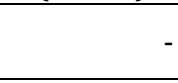 \\
\hline RIR & - & - & $\begin{array}{r}-0,025575 \\
(-1,163)\end{array}$ & $\begin{array}{r}-0,024284 \\
(-1,102)\end{array}$ \\
\hline $\mathrm{COM}$ & $\begin{array}{l}0,032416 \\
(2,356)^{* *}\end{array}$ & - & $\begin{array}{l}0,021336 \\
(2,081)^{* *}\end{array}$ & ( \\
\hline BRENT & 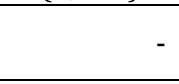 & $\begin{array}{l}0,033324 \\
(2,398)^{* *}\end{array}$ & 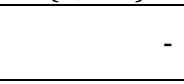 & $\begin{array}{l}0,021138 \\
(2,160)^{* *}\end{array}$ \\
\hline DUM_PEMILU & $\begin{array}{r}0,115991 \\
(0,338)\end{array}$ & $\begin{array}{r}0,110092 \\
(0,322)\end{array}$ & $\begin{array}{r}0,073238 \\
(0,249) \\
\end{array}$ & $\begin{array}{r}0,065539 \\
(0,223)\end{array}$ \\
\hline DUM98 & $\begin{array}{l}-3,405033 \\
(-2,230)^{* *}\end{array}$ & $\begin{array}{l}-3,509907 \\
(-2,255)^{* *}\end{array}$ & $\begin{array}{r}-2,157651 \\
(-3,735)^{* * *}\end{array}$ & $\begin{array}{r}-2,086204 \\
(-3,669)^{* * *}\end{array}$ \\
\hline ECT & $\begin{array}{r}-0,733034 \\
(-5,235)^{* * *}\end{array}$ & $\begin{array}{r}-0,728445 \\
(-5,222)^{* * *}\end{array}$ & $\begin{array}{r}-0,893749 \\
(-6,259)^{* * *}\end{array}$ & $\begin{array}{r}-0,901948 \\
(-6,304)^{* * *}\end{array}$ \\
\hline
\end{tabular}

Keterangan: ${ }^{* * *}=\operatorname{sig} .1 \%,{ }^{* *}=$ sig. $5 \%,{ }^{*}=$ sig. $10 \%$; $t$-statistic dalam kurung

Sumber: Hitungan penulis

Namun rasio utang terhadap PDB pada periode satu tahun sebelumnya memberikan dampak yang negatif sebesar 0,06 persen dan signifikan. Hasil ini bertolak belakang dengan hasil penelitian Lestari (2014) dan Pamungkas (2016) yang menunjukkan dampak yang positif. Hal ini mungkin dapat dijelaskan dengan adanya proses penyusunan target anggaran. Pemerintah dalam menyusun target keseimbangan primer yang terdiri target pendapatan dan anggaran belanja mungkin mempertimbangkan rasio utang periode dua tahun sebelumnya karena penyusunan anggaran yang dimulai dari sekitar bulan Mei tahun sebelumnya belum dapat digunakan untuk melihat gambaran rasio utang secara utuh pada periode satu tahun sebelumnya sehingga pemerintah hanya dapat menggunakan rasio utang dua tahun sebelumnya sebagai landasan untuk menentukan arah kebijakan fiskal yang berkesinambungan. Hal tersebut dapat dijelaskan dengan merujuk pada Grafik 2 mengenai perkembangan keseimbangan primer dan utang pemerintah dalam rasio PDB. Dapat terlihat misalnya pada tahun 1999, ketika utang meningkat tajam, rasio keseimbangan primer justru mengalami penurunan. Sesuai dengan hasil estimasi, rasio keseimbangan primer sepertinya tidak langsung merespon adanya peningkatan utang namun melihat pola beberapa periode sebelumnya.

Lebih lanjut reaksi yang bertolak belakang dari peningkatan beban utang yang menunjukkan indikasi tak berkesinambungan dalam jangka pendek mungkin terjadi akibat dilema yang dihadapi oleh pemerintah. Dalam beberapa periode, pemerintah menghadapi dilema dalam merespon peningkatan utang dengan meningkatkan surplus primer karena hal tersebut akan menyebabkan pengurangan belanja negara yang cukup besar.

Salah satu contohnya ada pada periode 2012- 2017 seperti dapat dilihat dalam Grafik 2, meskipun terdapat peningkatan rasio utang terhadap PDB, keseimbangan primer tetap berada dalam posisi negatif. Hal tersebut terjadi akibat adanya shock jangka pendek yakni turunnya harga komoditas yang menyebabkan ketidakpastian terutama dari sisi pendapatan pemerintah. Pendapatan pemerintah meleset dari target 
sehingga terjadi defisit yang lebih lebar. Namun demikian, shock jangka pendek tersebut baru dapat direspon pemerintah dengan upaya disiplin fiskal pada tahun 2016, yaitu dengan menyediakan bantalan fiskal, meningkatkan fleksibilitas pengelolaan fiskal serta mengendalikan kerentanan fiskal.

Di lain pihak, pemerintah juga memiliki berbagai agenda untuk menjalankan programprogram kesejahteraan rakyat dan fungsi stabilisasi yang harus dijalankan sehingga dalam jangka pendek kondisi intertemporal budget constraint adalah sulit untuk dipenuhi. Namun demikian, dalam konsep present value budget constraint, kesinambungan atau kointegrasi antara data variabel terjadi dalam jangka panjang dan adalah umum jika terjadi ketidaksinambungan atau respon yang tidak sesuai dalam jangka pendek. Jadhav dan Neelankavil (2011) menyatakan bahwa dalam jangka pendek defisit anggaran dapat terjadi untuk memenuhi kebutuhan negara namun harus diiringi dengan adanya rencana jangka panjang agar defisit tersebut hanya bertahan pada jangka pendek.

Dalam menjaga kesinambungan fiskal, pemerintah tidak saja dihadapkan pada pengendalian keseimbangan primer tetapi juga harus mempertimbangkan faktor-faktor lainnya. Beberapa tantangan yang harus dihadapi pemerintah antara lain adalah mobilisasi pendapatan, penguatan efektivitas bantuan sosial, subsidi dan TKDD (Transfer ke Daerah dan Dana Desa), efisiensi dan inovasi pembiayaan, penajaman belanja serta pengendalian mandatory spending.

Belanja mandatory spending APBN, yaitu 20 persen anggaran pendidikan dan 5 persen anggaran kesehatan mengakibatkan adanya keterbatasan dalam ruang gerak fiskal. Pengendalian mandatory spending dilakukan dengan peningkatan kualitas belanja yang lebih efektif, yaitu melalui realokasi dari belanja konsumtif (belanja barang) ke belanja modal, pegawai dan bantuan sosial serta melakukan monitoring dan review atas pelaksanaan belanja tersebut.

Reaksi fiskal dalam hal ini adalah perilaku pemerintah dalam mengatur kebijakan pendapatan dan belanja negara yang berdampak pada surplus defisit anggaran. Dari lima variabel dan dua dummy sebagai variabel penjelas yang memengaruhi reaksi fiskal, hanya beberapa variabel saja yang menunjukkan signifikansi pengaruh. Selain rasio utang terhadap PDB, dalam jangka panjang hanya nilai tukar dan dummy tahun 1998 yang berpengaruh terhadap rasio keseimbangan primer.

Nilai tukar berpengaruh signifikan terhadap kesinambungan sesuai dengan penelitian terdahulu
(Pamungkas, 2016; Insukindro, 2018; Nurhayati \& Wahyuningsih, 2018). Semakin tinggi nilai tukar riil maka semakin rendah nilai surplus primer. Ketika nilai tukar melemah, utang khususnya utang luar negeri cenderung mengalami peningkatan meskipun memang tidak dapat diketahui apakah memang terdapat peningkatan jumlah utang luar negeri ataukah memang ada faktor nilai tukar. Penurunan keseimbangan primer akibat penguatan nilai tukar selain disebabkan oleh respon terhadap beban utang juga merupakan implikasi dari pos-pos anggaran dengan mata uang dolar. Penguatan nilai tukar menyebabkan belanja dengan mata uang dolar seperti impor minyak akan semakin rendah namun juga menyebabkan pos pendapatan pemerintah yang berdenominasi dolar turun. Jika belanja dengan mata uang dolar memiliki proporsi yang besar maka hal ini dapat memberikan kelonggaran ruang fiskal namun jika pos pendapatan berkontribusi lebih besar maka akan terjadi defisit primer. Respon negatif atas peningkatan nilai tukar riil menunjukkan bahwa pada periode 1977-2017, pendapatan dalam mata uang dolar memiliki porsi lebih besar dari belanja. Untuk itu pemerintah harus memberi perhatian pada nilai tukar terutama dalam beberapa tahun terakhir ketika nilai tukar berfluktuasi yang dapat mengancam pendapat negara dan meningkatkan risiko fiskal.

Krisis yang terjadi di tahun 1998 berdampak signifikan bagi arah kebijakan fiskal. Hasil tersebut sesuai dengan penelitian sebelumnya, misalnya Ascarya dan Yumanita (2004), Cruz-Rodriguez (2014), Hakim dan Sriyana (2015), dan Pamungkas (2016). Adanya krisis menyebabkan pemerintah memperkecil surplus keseimbangan primernya. Sesuai dengan prinsip counter cyclical, pemerintah mengupayakan program untuk menyelamatkan keadaan perekonomian saat itu meskipun harus mengeluarkan dana yang tidak sedikit. Selain itu, kondisi krisis ekonomi membuat pemerintah kesulitan meningkatkan penerimaan pajak. Meskipun pada tahun 1998, output gap dan inflasi menunjukkan ekonomi yang sedang bekerja di atas kapasitas produksinya, namun pemerintah harus melakukan kebijakan fiskal yang bersifat ekspansif untuk meningkatkan daya beli masyarakat pada masa tersebut.

Hasil analisis menunjukkan bahwa harga komoditas tidak berpengaruh dalam jangka panjang namun signifikan dalam jangka pendek dapat dijelaskan melalui fluktuasi harga komoditas dan proporsi penerimaan negara yang terlihat pada Grafik 3. Peningkatan penerimaan negara yang tinggi namun bersifat sementara salah satunya dipengaruhi oleh harga komoditas yang meningkat sementara. Peningkatan harga komoditas yang 
bersifat sementara dapat diamati melalui peristiwa commodity boom (Azwar, 2015; Nizar, 2012) yang terjadi sekitar tahun 2000-an dan berakhir pada tahun 2012. Pada masa tersebut harga komoditas cenderung meningkat tajam bahkan mencapai harga tertingginya pada tahun 2012. Namun demikian seperti tampak pada Grafik 3, harga komoditas perlahan kembali pada titik seimbangnya.

Grafik 3. Harga Komoditas dan Pendapatan Sumber Daya Alam, 1977-2017

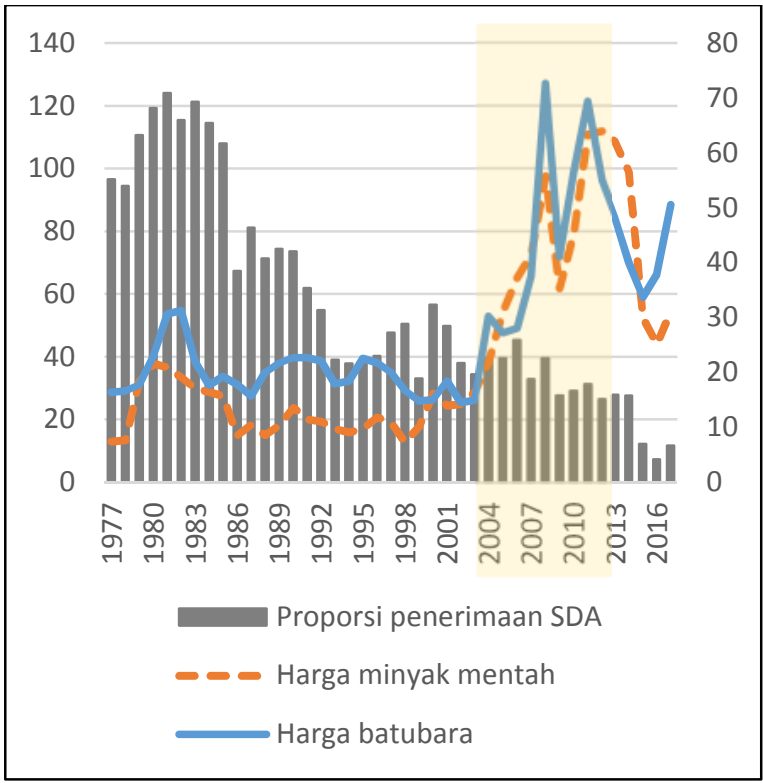

Sumber: diolah dari NK APBN dan World Bank (n.d.-a)

Selain itu seperti dapat dilihat dalam Grafik 3, meskipun harga komoditas mengalami fluktuasi, pemerintah telah melakukan antisipasi dengan menurunkan ketergantungan terhadap penerimaan dari sumber daya alam. Pendapatan dari komoditas merupakan salah satu kontribusi penerimaan negara cukup tinggi dalam beberapa dekade terakhir meskipun terus turun dalam beberapa tahun terakhir. Di tahun 1980-an pendapatan dari sumber daya alam menyumbang sekitar 70 persen dari penerimaan negara. Hal ini menyebabkan harga komoditas menjadi salah satu variabel yang penting untuk mengakomodasi tingginya ketergantungan terhadap penerimaan sumber daya alam. Fluktuasi terhadap harga komoditas hendaknya ditanggapi pemerintah dengan melakukan diversifikasi pendapatan agar kebijakan fiskal tetap stabil dan tidak bergantung pada fluktuasi harga.

Penelitian ini menggunakan harga komoditas karena dianggap dapat merepresentasikan bagian dari penerimaan negara yang berasal dari sumber daya alam. Ini berbeda dengan penelitian-penelitian sebelumnya (misalnya Suharsih, 2013; Wardhono et al., 2015; Pamungkas, 2016) yang menggunakan harga minyak saja sebagai variabel penjelas. Pamungkas (2016) misalnya menggunakan harga minyak internasional sebagai proksi dari harga minyak Indonesia karena series data Indonesia yang dimiliki relatif tidak cukup panjang. Penelitiannya menunjukkan tanda negatif karena selain harga minyak memengaruhi pendapatan negara juga menunjukkan adanya beban pada belanja impor minyak untuk subsidi yang lebih tinggi. Selain itu, dalam periode observasi pada penelitian Pamungkas (2016), jumlah belanja terkait subsidi sudah lebih tinggi dibandingkan pendapatannya sehingga memberikan tanda koefisien yang berbeda. Dengan demikian, perbedaan arah dengan hasil temuan pada penelitian ini menunjukkan bahwa rata-rata pada periode 1977-2017, pendapatan negara dari sumber daya alam lebih tinggi dari belanja produk komoditas seperti minyak untuk subsidi sehingga efek pendapatan lebih terlihat dan dapat meningkatkan surplus keseimbangan primer.

Selanjutnya, Suharsih (2013) menunjukkan bahwa fluktuasi harga minyak dapat mengancam sustainabilitas fiskal mengingat posisi Indonesia sebagai negara pengimpor minyak. Di lain pihak, Mokoginta \& Stephanie (2015) menemukan bahwa harga minyak Indonesia (ICP) tidak signifikan memengaruhi kesinambungan fiskal. Senada dengan penelitian-penelitian Suharsih (2013) dan Pamungkas (2016), penelitian ini menemukan bahwa harga minyak internasional dan harga komoditas secara signifikan memengaruhi keseimbangan fiskal dalam jangka pendek. Dengan demikian, harga komoditas dapat dipergunakan sebagai variabel independen dalam penelitian kesinambungan fiskal, dimana penelitian selama ini terbatas menggunakan variabel harga minyak internasional.

Tiga variabel kontrol yang sering dipakai dalam penelitian-penelitian sebelumnya namun terbuki tidak signifikan dalam penelitian ini adalah inflasi, tingkat bunga, dan dummy pemilihan umum. Hasil tentang dummy pemilu ini berbeda dengan hasil penelitian Pamungkas (2016) yang menemukan bahwa faktor pemilu berpengaruh negatif (signifikan pada level 1 persen) terhadap kesinambungan fiskal. Hasil penelitian ini tidak dapat mengkonfirmasi peningkatan belanja menjelang pemilu (Ebeke \& Ölçer, 2013) sebagai upaya menarik minat pemegang suara. Jika hasil tersebut benar, kita patut bersyukur apabila sifat dan kualitas infrastruktur politik (Mandon \& Cazals, 2019) membuat Indonesia terhindar dari praktik buruk tersebut. 
Selain itu, dari hasil regresi dapat diketahui bahwa penggunaan variabel riil (misalnya nilai tukar riil, RER) lebih baik daripada nilai tukar nominal (misalnya nilai tukar nominal, ER). Penggunaan nilai riil akan menghilangkan faktor inflasi dan menggambarkan kondisi perekonomian yang sesungguhnya. Praktik ini standar dilakukan dalam analisis ekonomi, meskipun dalam kenyataannya masih sering ditemukan penggunaan variabel nominal.

\section{KESIMPULAN DAN SARAN}

Kesinambungan merupakan salah satu aspek yang penting dalam mengelola kebijakan fiskal pemerintah. Dalam kerangka present value budget constraint, konsep kesinambungan fiskal merujuk pada kemampuan pemerintah untuk membayar kembali utang sehingga tidak terdapat akumulasi utang yang terus menerus. Dengan menggunakan metode persamaan reaksi fiskal yang diestimasi dengan ARDL-ECM, penelitian ini menemukan bahwa pemerintah memberikan respon atas peningkatan beban utang sehingga kebijakan fiskal di Indonesia pada periode 1977-2017 diindikasikan berkesinambungan.

Cara untuk menjaga kesinambungan fiskal misalnya dengan menetapkan aturan fiskal (fiscal rules) tentang batasan belanja atau defisit sebagai alat kontrol (Lau \& Syn-Yee, 2018). Sebagaimana disebutkan sebelumnya, aturan tentang hal tersebut sudah ada di Indonesia, sehingga tantangannya adalah bagaimana menerapkan aturan tersebut dalam bentuk kehati-hatian dalam pengelolaan APBN. Selain optimalisasi pengelolaan utang, keberlanjutan dan kredibilitas kebijakan fiskal juga ditentukan oleh peningkatan penerimaan negara dan perbaikan kualitas belanja (Widjojo, 2017). Spending review perlu dilakukan untuk memperbaiki peningkatan kualitas belanja. Belanja yang produktif diharapkan dapat meningkatkan perekonomian di masa mendatang sehingga pemerintah memiliki kemampuan untuk memperoleh pendapatan dengan lebih baik di masa mendatang. Selain itu, perlu dilakukan perencanaan kebijakan fiskal jangka menengah (medium term fiscal framework) sehingga pengambil kebijakan memiliki koridor untuk menyusun kebijakan fiskal yang sehat dan berkesinambungan dalam jangka menengah dan panjang.

Selain mengidentifikasi apakah terdapat kesinambungan fiskal pada periode 1977-2017, penelitian ini juga mengestimasi pengaruh variabel ekonomi makro dan sosial/politik (yaitu output gap, inflasi, nilai tukar, suku bunga, harga komoditas, peristiwa pemilu, dan krisis ekonomi Asia tahun
1998) terhadap keseimbangan primer. Hasil penelitian ini menunjukkan bahwa nilai tukar dan krisis Asia tahun 1998 berpengaruh signifikan terhadap keseimbangan primer dalam jangka panjang, sedangkan nilai tukar riil, krisis Asia tahun 1998 dan harga komoditas berpengaruh signifikan dalam jangka pendek. Sementara itu output gap, inflasi, suku bunga, harga komoditas, dan peristiwa pemilu tidak memberikan pengaruh yang signifikan terhadap keseimbangan primer pada periode yang dianalisis. Bahwa variabel kurs yang signifikan memengaruhi kesinambungan fiskal perlu dijadikan pertimbangan bagi pemerintah utuk mencari sumber pembiayaan lewat utang dalam negeri (Insukindro, 2018).

\section{IMPLIKASI DAN KETERBATASAN}

Konsep kesinambungan fiskal merupakan konsep yang luas dan banyak peluang dikembangkan. Penelitian kali ini hanya merupakan bagian kecil dari konsep kesinambungan fiskal dan hanya menilai kesinambungan dari arah keseimbangan primer yang menjadi indikator reaksi pemerintah. Untuk itu penelitian terkait kesinambungan fiskal pemerintah masih bisa dikembangkan lebih luas lagi dengan berbagai pendekatan yang lebih luas tidak hanya melihat kesinambungan dari perilaku pemerintah namun juga dari kondisi makro ekonomi.

Persamaan reaksi fiskal juga dapat dikembangkan lebih lanjut lagi baik menambah variabel kontrol yang menjelaskan determinan keseimbangan primer di Indonesia maupun dengan menambah tahun observasi mengingat jumlah observasi dalam penelitian ini cukup terbatas. Jumlah observasi dalam penelitian ini yang tidak terlalu banyak cukup membatasi ruang untuk menambah dummy dan variabel, sehingga penambahan tahun observasi selain menambah ruang untuk menambah variabel juga dapat memberikan pandangan yang baru seiring dengan perubahan dinamika perekonomian.

Penelitian ini menggunakan metode ARDL yang relatif sederhana. Metode estimasi persamaan reaksi fiskal dapat dikembangkan dengan metode pengolahan yang berbeda. Namun demikian, berbagai metode lain yang dapat digunakan mungkin lebih baik namun lebih kompleks dan mempunyai tingkat kesulitan yang lebih tinggi. Salah satu pendekatan yang menarik untuk dilakukan adalah penggunaan time-varying models (misalnya Campos \& Cysne, 2019) yang dapat mengestimasi fungsi reaksi fiskal pada setiap titik sepanjang periode observasi. 


\section{PENGHARGAAN}

Penulis menyampaikan ucapan terima kasih kepada R. H. Pamungkas dari Badan Kebijakan Fiskal atas bantuan dan sarannya yang berharga. Meskipun demikian, penulis bertanggung jawab sepenuhnya atas hasil penelitian.

\section{REFERENSI}

Adams, C., Ferrarini, B. \& Park, D. (2010). Fiscal sustainability in developing asia. ADB Economics Working Paper Series No. 205. Manila: ADB.

Ascarya \& Yumanita, D. (2004). Utang pemerintah dan kesinambungan fiskal. Jurnal Ekonomi dan Kewirausahaan, 3(1), 1-26.

Aso, Y. (2013). Sustainability of budget deficits. Public Policy Review, 9(4), 661-686.

Azwar. (2015). Dampak perubahan harga crude palm oil (CPO) terhadap value ekspor komoditas kelapa sawit dan perekonomian Indonesia (Pendekatan vector autoregression analysis). Jurnal Info Artha, 2, 1-17.

Bank Indonesia. (n.d.). Statistik Ekonomi dan Keuangan Indonesia (SEKI). Diambil 24 September 2018, dari https://www.bi.go.id/id/ statistik/seki/terkini/moneter/Contents/Def ault.aspx

Bohn, H. (2005). The sustainability of fiscal policy in the United States. CESifo Working Paper No. 1446. Santa Barbara: CESifo.

Bohn, H. (2007). Are stationarity and cointegration restrictions really necessary for the intertemporal budget constraint? Journal of Monetary Economics, 54(7), 1837-1847. https://doi.org/10.1016/j.jmoneco.2006.12.0 12

Bui, D. (2019). Fiscal sustainability in developing Asia - new evidence from panel correlated common effect model. Journal of Asian Business and Economic Studies, Vol. ahead-of-print (No. ahead-of-print). 10.1108/JABES-01-2019-0001

Campos, E. L. \& Cysne, R. P. (2019). A time varying fiscal reaction function for Brazil. Estudos Economicos (Sao Paulo), 49(1), 5-38. http://dx.doi.org/10.1590/0101$41614911 \mathrm{ecr}$

Combes, J.-L., Minea, A. \& Sow, M. (2017). Is fiscal policy always counter- (pro-) cyclical? The role of public debt and fiscal rules. Economic
Modelling, 65, 138-146. http://dx.doi.org/ 10.1016/j.econmod.2017.05.017

Cruz-Rodriguez, A. (2014). Assessing fiscal sustainability in some selected countries. Theoretical and Applied Economics, 21(6), 7-22.

Cuddington, J. T. (1997). Analysing the Sustainability of Fiscal Deficits in Developing Countries. World Bank Research Working Paper No. 1784. Washington: World Bank.

Dinh, H. T. (1999). Fiscal Solvency and Sustainability in Economic Management. World Bank Policy Research Working Paper No. 2213. Washington: World Bank.

Direktorat Jenderal Pengelolaan dan Pembiayaan Risiko Kementerian Keuangan. (n.d.). Posisi Utang Pemerintah Pusat. Diambil 17 September 2018, dari ttp://www.djppr. kemenkeu.go.id/page/load/21.

DJA. (2019). Informasi APBN 2019. Jakarta: Direktorat Jenderal Anggaran, Kementerian Keuangan.

Ebeke, C. \& Ölçern, D. (2013). Fiscal policy over the election cycle in low-income countries. IMF Working Paper WP/13/153. International Monetary Fund.

Federal Reserve Bank of St. Louis. (n.d.-a). Crude Oil Prices: West Texas Intermediate (WTI) Cushing, Oklahoma. Diambil 11 Desember 2018, dari https://fred.stlouisfed.org/series/ DCOILWTICO.

Federal Reserve Bank of St. Louis. (n.d.-b). Inflation, Consumer Prices for Indonesia. Diambil 6 November 2018, dari https://fred.stlouisfed. org/series/FPCPITOTLZGIDN

Gujarati, D. N. (2003). Basic Econometric (4th Ed). West Point: McGraw-Hill Higher Education.

Hakim, A. \& Sriyana, J. (2015). Debt-to-GDP ratio for fiscal sustainability in Indonesia: A conditional value-at-risk approach. International Journal of Economic Research, 12(4), 1019-1027.

Hakkio, C. S., \& Rush, M. (1991). Is the budget deficit "too large?" Economic Inquiry, 29(July), 429445.

Insukindro. (2018). The effect of twin shock on fiscal sustainability in Indonesia. Economics and Sociology, 11(1), 75-84. https://doi.org/ 10.14254/2071-789X.2018/11-1/5

Jadhav, A. \& Neelankavil, J. (2011). Deficit financing: Causes, consequences, and potential cures. The Journal of Applied Business and Economics, 12(6), 83-99. 
Kuncoro, H. (2011). The sustainability of state budget in debt repayment. Bulletin of Monetary, Economic, and Banking, April, 415434.

Lau, E. \& Syn-Yee, A. L. (2018). Estimating fiscal reaction functions in Malaysia, Thailand, and the Philippines. Jurnal Ekonomi Malaysia, 52(1), 67-76. http://dx.doi.org/10.17576/ JEM-2018-5201-6

Lestari, T. (2014). Can Indonesia's fiscal policy be sustained with exploding debt? Working Paper in Economics and Development Studies (UNPAD) No. 201415. Bandung: UNPAD.

Mandon, P. \& Cazals, A. (2019). Political budget cycles: Manipulation by leaders versus manipulation by reaerchers? Evidence from a meta regression analysis. Journal of Economic Surveys, 33(1), 274-308. doi: 10.1111/ joes. 12263

Marisa, R. (2015). Analisis keberlanjutan fiskal Indonesia tahun 2000-2012. Bina Ekonomi, 19(1), 1-14.

Marks, S. V. (2004). Fiscal sustainability and solvency: Theory and recent experience in Indonesia. Bulletin of Indonesia Economic Studies, 40(2), 227-242. https://doi.org/ $10.1080 / 0007491042000205295$

Mokoginta, I. S., \& Stephanie, R. M. (2015). Structural breaks and fiscal sustainability of the Indonesian government budget. Economic Journal of Emerging Markets, 7(1), 33-47. https://doi.org/http://dx.doi.org/10.20885/e jem .vol7.iss1.art4

Mudayen, Y. M. V. (2017). The impact of government foreign debt on fiscal sustainability in Indonesia. International Journal of Economics and Financial Issues, 7(3), 746-751.

Nizar, M. A. (2012). Dampak fluktuasi harga minyak dunia terhadap perekonomian Indonesia. Buletin Ilmiah Litbang Perdagangan, 6(2), 189210.

Nurhayati \& Wahyuningsih, M. (2018). Analisis kesinambungan fiskal pada variabel makroekonomi Indonesia periode 1998-2017. Prosiding Seminar Nasional Cendekiawan ke-4 Tahun 2018 Buku II. Jakarta: Universitas Trisakti.

Oyeleke, O. J., \& Adebisi, D. G. (2014). Econometric analysis of fiscal deficit sustainability of Ghana. Journal of Economics and Sustainable Development, 5(28), 34-41.
Pamungkas, R. H. (2016). Estimation of Indonesia's fiscal reaction function. Kajian Ekonomi dan Keuangan, 20(1), 1-18.

Paparas, D., Richter, C. \& Paparas, A. (2015). A synthesis of empirical research in the sustainability of fiscal policy. Journal of Economics Bibliography, 2(4), 165-183.

Pesaran, M. H., Shin, Y. \& Smith, R. J. (2001). Bounds testing approaches to the analysis of level relationships. Journal of Applied Econometrics, 16(3), 289-326. https://doi.org/10.1002/ jae.616

Quintos, C. E. (1995). Sustainability of deficit process with structural shift. Journal of Business dan Economics Statistics, 13(4), 409417.

Rahmany, A. F. (2009). Ketahanan fiskal dan manajemen utang dalam negeri pemerintah. In Abimanyu, A. \& Megantara, A. (Eds.), Era Baru Kebijakan Fiskal: Pemikiran, Konsep dan Implementasi. Jakarta: Kompas.

Ramadhan, G., \& Simanjuntak, R. A. (2007). Dinamika utang pemerintah dan kesinambungan fiskal di Indonesia periode 1980-2005: Suatu uji perbandingan tiga pendekatan. Jurnal Ekonomi dan Pembangunan Indonesia, 8(1), 1-30.

Solikin, A. (2018). Pengeluaran pemerintah dan perkembangan perekonomian (Hukum Wagner) di negara sedang berkembang: Tinjauan sistematis. Jurnal Info Artha, 2(1), 5364.

Sriyana, J. (2012). Dinamika Kinerja Fiskal di Indonesia. Yogyakarta: UII Press.

Suharsih, S. (2013). Fluktuasi harga minyak dunia dan pencapaian sustainabilitas fiskal Indonesia. Kinerja, 17(1), 28-44.

Tanner, E., \& Samake, I. (2008). Probabilistic sustainability of public debt: A vector autoregression approach for Brazil, Mexico, and Turkey. IMF Staff Papers, 55(1), 149-182. https://doi.org/10.1057/palgrave.imfsp.9450 029

Trehan, B., \& Walsh, C. E. (1991). Testing intertemporal budget constraints: Theory and applications to U. S. Federal Budget and current account deficits. Journal of Money, Credit and Banking, 23(2), 206. https://doi.org/10.2307/1992777

Tronzano, M. (2013). The Sustainability of Indian fiscal policy: A reassessment of the empirical evidence. Emerging Markets Finance and 
Trade, 49(0), 63-76. https://doi.org/ 10.2753/REE1540-496X4901S105

Wardhono, A., Qori'ah, C. G. \& Wulandari, C. D. A. (2015). Studi kesinambungan fiskal pada variabel makro ekonomi Indonesia: Analisis VAR. Jurnal Ekonomi Kuantitatif Terapan, 8(2), 113-121.

Wickens, M. (2008). Macroeconomic Theory: A Dynamic General Equilibrium Approach. New Jersey: Princeton University Press.

Widjojo, P. (2017). Menjaga kesinambungan fiskal untuk pertumbuhan yang berkualitas. Dalam Tim Indef (Ed.). Menuju Ketangguhan Ekonomi: Sumbang Saran 100 Ekonom Indonesia. Jakarta: Penerbit Buku Kompas.

World Bank. (n.d.-a). Commodity Prices. Diambil 4 November 2018, dari http://www.worldbank. org/en/research/commodity-markets

World Bank. (n.d.-b). Real Interest Rate \%. Diambil 27 September 2018, dari https://data. worldbank.org/indicator/FR.INR.RINR?locati ons=IDdanview $=$ chart

Zhang, P. (2015). Facing fiscal crisis: Managing counter-cyclical debt financing of the state and local government. Journal of Public Budgeting, Accounting \& Financial Management, 27(4), 523-545. 
LAMPIRAN

Uji Lag Optimum 1a, 1b, 1c, 1d

\begin{tabular}{ccccccc}
\hline \hline Lag & LogL & LR & FPE & AIC & SC & HQ \\
\hline \hline 0 & -1398.579 & NA & $6.64 \mathrm{e}+23$ & 74.71471 & 75.61969 & 75.03670 \\
1 & -1196.828 & 297.3182 & $2.33 \mathrm{e}+20$ & 66.67515 & $69.69175^{\star}$ & 67.74843 \\
2 & -1132.828 & 70.73690 & $1.56 \mathrm{e}+20$ & 65.88567 & 71.01390 & 67.71026 \\
3 & -1042.381 & $66.64504^{\star}$ & $5.28 \mathrm{e}^{+19^{*}}$ & $63.70426^{\star}$ & 70.94411 & $66.28014^{\star}$ \\
\hline \hline
\end{tabular}

* indicates lag order selected by the criterion

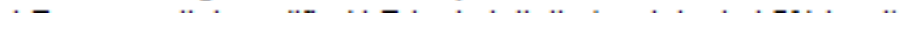

\begin{tabular}{ccccccc}
\hline \hline Lag & LogL & LR & FPE & AIC & SC & HQ \\
\hline \hline 0 & -1399.746 & NA & $7.06 \mathrm{e}+23$ & 74.77613 & 75.68111 & 75.09811 \\
1 & -1195.938 & 300.3495 & $2.23 \mathrm{e}+20$ & 66.62831 & $69.64491^{\star}$ & 67.70159 \\
2 & -1130.752 & $72.04753^{*}$ & $1.40 \mathrm{e}+20$ & 65.77642 & 70.90465 & 67.60101 \\
3 & -1044.554 & 63.51434 & $5.92 \mathrm{e}+19^{*}$ & $63.81863^{\star}$ & 71.05848 & $66.39451^{\star}$ \\
\hline \hline
\end{tabular}

* indicates lag order selected by the criterion

\begin{tabular}{ccccccc}
\hline \hline Lag & LogL & LR & FPE & AIC & SC & HQ \\
\hline \hline 0 & -1297.661 & NA & $3.27 \mathrm{e}+21$ & 69.40321 & 70.30819 & 69.72519 \\
1 & -1107.781 & 279.8229 & $2.15 \mathrm{e}+18$ & 61.98848 & $65.00509^{\star}$ & 63.06177 \\
2 & -1029.986 & 85.98406 & $6.96 \mathrm{e}+17$ & 60.47295 & 65.60118 & 62.29753 \\
3 & -936.9322 & $68.56598^{\star}$ & $2.05 \mathrm{e}+17^{\star}$ & $58.15433^{\star}$ & 65.39418 & $60.73021^{\star}$ \\
\hline \hline
\end{tabular}

* indicates lag order selected by the criterion

\begin{tabular}{ccccccc}
\hline \hline Lag & LogL & LR & FPE & AIC & SC & HQ \\
\hline \hline 0 & -1299.308 & NA & $3.57 \mathrm{e}+21$ & 69.48988 & 70.39486 & 69.81186 \\
1 & -1108.884 & 280.6246 & $2.28 \mathrm{e}+18$ & 62.04652 & $65.06312^{\star}$ & 63.11980 \\
2 & -1030.182 & 86.98662 & $7.03 \mathrm{e}+17$ & 60.48324 & 65.61147 & 62.30783 \\
3 & -935.3010 & $69.91204^{*}$ & $1.88 \mathrm{e}+17^{\star}$ & $58.06847^{\star}$ & 65.30833 & $60.64436^{*}$ \\
\hline \hline
\end{tabular}

* indicates lag order selected by the criterion 
Uji Kointegrasi Model 1a, 1b, 1c, 1d

ARDL Bounds Test

Date: $12 / 11 / 18$ Time: $08: 26$

Sample: 19792017

Included observations: 39

Null Hypothesis: No long-run relationships exist

\begin{tabular}{|c|c|c|}
\hline Test Statistic & Value & k \\
\hline F-statistic & 5.409982 & 6 \\
\hline \multicolumn{3}{|c|}{ Critical Value Bounds } \\
\hline Significance & 10 Bound & I1 Bound \\
\hline $10 \%$ & 2.12 & 3.23 \\
\hline $5 \%$ & 2.45 & 3.61 \\
\hline $2.5 \%$ & 2.75 & 3.99 \\
\hline $1 \%$ & 3.15 & 4.43 \\
\hline
\end{tabular}

ARDL Bounds Test

Date: 12/11/18 Time: 08:50

Sample: 19792017

Included observations: 39

Null Hypothesis: No long-run relationships exist

\begin{tabular}{lll}
\hline \hline Test Statistic & Value & $k$ \\
\hline \hline F-statistic & 6.284771 & 6
\end{tabular}

ARDL Bounds Test

Date: 12/11/18 Time: 08:36

Sample: 19792017

Included observations: 39

Null Hypothesis: No long-run relationships exist

\begin{tabular}{lll}
\hline \hline Test Statistic & Value & $\mathrm{k}$ \\
\hline \hline F-statistic & 5.443685 & 6 \\
\hline \hline
\end{tabular}

\begin{tabular}{lcc}
\hline \hline \multicolumn{3}{l}{ Critical Value Bounds } \\
\hline \hline Significance & 10 Bound & 11 Bound \\
\hline \hline $10 \%$ & 2.12 & 3.23 \\
$5 \%$ & 2.45 & 3.61 \\
$2.5 \%$ & 2.75 & 3.99 \\
$1 \%$ & 3.15 & 4.43 \\
\hline \hline
\end{tabular}

ARDL Bounds Test

Date: $12 / 11 / 18$ Time: 08:57

Sample: 19792017

Included observations: 39

Null Hypothesis: No long-run relationships exist

\begin{tabular}{|c|c|c|c|c|c|}
\hline F-statistic & 6.284771 & 6 & F-statistic & 6.411004 & 6 \\
\hline \multicolumn{3}{|c|}{ Critical Value Bounds } & \multicolumn{3}{|c|}{ Critical Value Bounds } \\
\hline Significance & 10 Bound & I1 Bound & Significance & 10 Bound & 11 Bound \\
\hline $10 \%$ & 2.12 & 3.23 & $10 \%$ & 2.12 & 3.23 \\
\hline $5 \%$ & 2.45 & 3.61 & $5 \%$ & 2.45 & 3.61 \\
\hline $2.5 \%$ & 2.75 & 3.99 & $2.5 \%$ & 2.75 & 3.99 \\
\hline $1 \%$ & 3.15 & 4.43 & $1 \%$ & 3.15 & 4.43 \\
\hline
\end{tabular}

